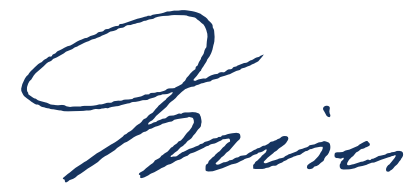

\title{
Da Governança surge um Mercado
}

\author{
Francisco Litvay*
}

GEBEL, T. Free Private Cities: Fazendo Governos Competirem por Você. Scotts Valley: Amazon Publishing, 2019. 312p.

Grandes intelectuais são responsáveis pelo desenvolvimento de ideias. Grandes empreendedores são responsáveis por colocá-las em prática. Em Free Private Cities: Fazendo Governos Competirem por Você, vemos um autor e empresário aplicar as ideias da Escola Austríaca sobre a superioridade econômica da competição de mercado para radicalmente transformar o panorama da governança.

Nesta obra, Titus Gebel desenvolve a ideia de Free Private Cities (Cidades Privadas Livres) e se aprofunda em como elas podem ser implementadas. Primeiro, é importante definir o que se entende pelo conceito: uma cidade privada livre é, em muitos sentidos, semelhante às denominadas "charter cities": Uma zona especial, territorialmente limitada, com grande autonomia para escolher seu próprio sistema jurídico. A diferença, no entanto, está na base subjacente da estrutura de governança, que, neste caso, é um contrato individual entre o operador da cidade e o cidadão.

Para quem vê no mútuo consentimento o verdadeiro alicerce das relações humanas, não é difícil perceber a significância dessa diferença. Não mais os governantes se referem a um abstrato contrato social que, na melhor das hipóteses, possui concordância implícita e, na pior delas, expressa desaprovação. Agora, a ordem pública é legitimada como uma relação contratual. Não é difícil imaginar possíveis implicações para o império da lei, já que a justificabilidade das ações tomadas pelo município é maior.

Com certeza, basear as relações em um contrato, tem muitas implicações para a estrutura jurídica do município. Muitas mudanças operacionais são derivadas da mudança do paradigma de governança dos estados tradicionais para o direito privado com consentimento explícito. 
A possibilidade de processar o operador da cidade, em tribunais independentes por violação de contrato, bem como o direito do cidadão de encerrar a relação a qualquer momento, são algumas das consequências encontradas no livro.

Em relação à posse da comunidade, diferentes modelos são propostos e avaliados, mas nenhum é mandatório. Entre as opções, estão regimes em que o operador detém toda a propriedade e arrenda lotes para cidadãos (leasehold) ou modelos em que os cidadãos detêm a propriedade do lote sob convênio e zonas públicas são administradas pelo operador (freehold) (BRUNETTA; MORONI, 2012). Ou seja, cidades privadas podem ser comunidades proprietárias, tanto como podem ser organizadas como uma enorme associação de moradores. Diversos mecanismos de participação também são considerados, entre eles os mais notáveis são a "democracia acionária", na qual a companhia emite ações e a participação dos cidadãos é organizada como a de um acionista de uma corporação. Bem como a "dupla democracia", modelo teorizado por Tom W. Bell (2017), que combina o "uma ação - um voto" para criação e execução de regras e "uma pessoa - um voto" para se vetar regras, que podem ser lucrativas, mas prejudicar a comunidade como um todo.

Embora o autor desenvolva as políticas e serviços de sua cidade ideal - uma cidade com livre mercado e fortes direitos individuais, basicamente um Estado mínimo operado por uma empresa, ele mesmo afirma que o conceito mais amplo de Cidade Privada Livre pode ser aplicado a muitos modelos sociais diferentes. Sendo que a única exigência é que as pessoas os escolham voluntariamente por contrato. As alternativas propostas são extremamente variadas, indo de comunidades étnicas e religiosas à aldeias com profunda conexão com a natureza. Do kibutz à cidade smart, rodando em blockchain, as possibilidades são enormes.

Não só essa variedade de alternativas é considerada possível. Na verdade, ela é ativamente encorajada. Uma das maiores vantagens que o autor enxerga na existência de várias cidades com sistemas legais distintos seguindo esse arranjo é que isso aumenta a variedade de modelos para se escolher. Por consequência, mais escolhas neste segmento aumentariam a concorrência jurisdicional, uma vez que os cidadãos-clientes votam com seus pés e investimentos. Isso, aliado ao alinhamento correto dos incentivos presentes na iniciativa privada, permite que as forças de mercado operem com maior amplitude no setor de governança. Os benefícios, advindos da competição e cooperação de mercado, poderiam então se manifestar nesse "mercado de viver juntos".

Quanto à estrutura, o livro está dividido em 4 partes, compostas por 27 capítulos, nos quais Titus primeiro estabelece as bases para o modelo, explica o conceito e as questões relativas à implementação e, finalmente, compartilha suas ideias sobre as perspectivas futuras para o desenvolvimento deste tipo de empresa.

Leitores interessados em tentar desenvolver uma cidade baseada nessa ideia tirarão grande proveito dos capítulos 12 a 24, que contêm os detalhes sobre a implementação de uma Cidade Privada Livre.

É importante ressaltar que o próprio autor afirma que, na maioria dos casos, é necessária uma mudança legislativa no país anfitrião para que esse tipo de empreitada seja ao menos possível. Os interessados em tornar esse tipo de projeto juridicamente viável na sua região terão grande interesse nos capítulos 6 a 8 e 25 a 27. Isso, para ter uma boa perspectiva da proposta de uma Cidade Privada, seus benefícios e para saber que objeções podem ser feitas a elas. 
Já estudiosos, querendo entender a origem dessa ideia, quais demandas sociais ela visa suprir, encontrarão mais valor nos capítulos 1 a 5. Quanto a quem está em busca de exemplos históricos e contemporâneos comparáveis ou precedentes para este tipo de regulação privada, poderá encontrar o respaldo que quer nos capítulos 9 a 11.

Concluo essa resenha, assim como o autor conclui o seu livro, de forma otimista. A crescente adoção de Zonas Econômicas Especiais, tanto em número quanto em escopo pelos países mundo afora, criam um ambiente cada vez mais propício para esse tipo de iniciativa ser testada, enquanto a popularização das comunidades empresariais e os desenvolvimentos nos seus modelos de gestão também atestam sua escalabilidade.

Cidades Empresariais já não são mais uma questão de "e se?", mas de "quando e onde?". E com o próprio autor fundando uma empresa homônima para essa empreitada, o tema deve permanecer interessante pelos próximos tempos.

\section{Referências:}

BELL, T. W. Your next government?: From the nation state to stateless nations. Londres: Cambridge University Press, 2017.

BRUNETTA, G.; MORONI, S. Brunetta, Contractual communities in the self-organising city: freedom, creativity, subsidiarity. Berlim: Springer Science \& Business Media, 2012.

RECEBIDO EM: 04/07/2019

APROVADO EM: 25/07/2019 